\title{
Morbidity and Mortality of Hepatic Right Lobe Living Donors: Systematic Review and Perspectives
}

\author{
Pauline Brige $^{1}$, Géraldine Hery ${ }^{1,2}$, Sophie Chopinet $^{1,3}$, Anaïs Palen ${ }^{1,3}$, Daniel Azoulay ${ }^{4,5}$, Emilie Gregoire ${ }^{1,3}$
}

\author{
1) Aix-Marseille University, \\ Experimental Interventional \\ Imaging Laboratory, European \\ Center for Medical Imaging \\ Research, Marseille; \\ 2) Aix-Marseille University, \\ Department of Pediatric \\ Surgery and Liver \\ Transplantation, Hôpital de la \\ Timone Enfant, Marseille; \\ 3) Aix-Marseille University, \\ Department of General \\ Surgery and Liver \\ Transplantation, Hôpital de la \\ Timone, Marseille; \\ 4.) epartment of HPB Surgery \\ and Liver Transplantation, \\ Hôpital Henri-Mondor, \\ Créteil; \\ 5) University Paris Est \\ Créteil, Mondor Institute of \\ Biomedical Research, \\ INSERM U955, \\ France
}

\author{
Address for correspondence: \\ Dr. Emilie Gregoire \\ Service de Chirurgie Digestive \\ et Transplantation Hépatique \\ Hôpital de la Timone \\ 264 rue Saint Pierre \\ 13365 Marseille cedex 5, \\ France
}

emilie.gregoire@ap-hm.fr

Received: 16.01.2018

Accepted: 28.04.2018

\section{ABSTRACT}

Background \& Aims: The main restriction in the development of adult-adult Living Donor Liver Transplantation (LDLT) is the risk of morbidity and mortality for donors, which raises ethical questions. The objectives of this study are to review published studies dealing with morbidity and mortality in LDLT and to identify the proposed management and strategies for preventing donor mortality and morbidity in LDLT. Methods: The Medline database was searched from 2000 to 2017 using the MeSH terms "liver transplantation" and "morbidity" or "mortality" in combination with keywords "living donor liver transplantation".

Results: Among the 382 articles obtained, 43 articles were relevant for morbidity, 15 for mortality and 6 for both morbidity and mortality. Twenty-three papers reported donor deaths. The major cause of death was sepsis (30\%). Morbidity ranged from $10 \%$ to $78.3 \%$ depending on the studies.

Conclusions: The living donors' morbidity and mortality is high, currently representing the main restriction in the development of LDLT. Some promising techniques, such as the donor portal vein flow modulation could lead to the further development of LDLT.

Key words: living donor - living donor liver transplantation - morbidity - mortality - preconditioning.

Abbreviations: LDLT: Living Donor Liver Transplantation; LL: Left Lobe; MELD: Model for End-Stage Liver Disease; RL: Right Lobe; SFSS: Small For Size Syndrome.

\section{INTRODUCTION}

Liver transplantation is a worldwide standard treatment for end-stage liver disease and for some specific stages of hepatocellular carcinoma. However, there has been an acute shortage of liver grafts from deceased donors for many years. Subsequently, the dropout of patients due to progression of disease and the mortality rate during the waiting time are both increasing, according to data from the French National Transplantation Agency ("Agence de Biomédecine") (Table I). Similar data are reported in North America [1,2]. This growing gap between the number of deceased donor organs and the number of patients on the waiting list for liver transplantation has motivated the use of other sources of grafts, such as living donor liver transplantation (LDLT).

The principle of LDLT is based on the ability of the liver parenchyma to regenerate. Indeed, the liver is comprised of autonomous vascular territories, allowing the division of the liver into different partial grafts. The effective liver regeneration is possible if $30 \%$ of its initial mass is respected, which corresponds on average to $0.5 \%$ of the individual's body weight [3]. On the other hand, the necessary mass of liver parenchyma for the recipients is at least $1 \%$ of their body weight. Therefore, the right liver is often chosen in order to achieve the receiver needs.

Historically, the first attempt of adult-child LDLT was made by Raia et al. [4] in Brazil in 1988, who described two failed cases despite a successful procedure. The first successful LDLT adult-child (left lobe) was performed in 1989 in Brisbane, Australia to overcome the lack of suitable grafts for pediatric recipients [5].

The technique was then extended to adult recipients (1993: first successful adult-adult LDLT using a left liver lobe [6]; 1996: first adult-adult LDLT from a right liver lobe [7]) in order to solve the shortage of deceased donor grafts and provide a source of grafts in countries where the recovery of deceased 
Table I. Liver transplantation waiting list "Agence de Biomédecine"

\begin{tabular}{|c|c|c|c|c|c|c|c|c|c|}
\hline & 2009 & 2010 & 2011 & 2012 & 2013 & 2014 & 2015 & 2016 & 2017 \\
\hline \multicolumn{10}{|l|}{ Waiting list } \\
\hline - Patients remaining on waiting list on 1st January of each year & 669 & 806 & 932 & 941 & 1106 & 1267 & 1297 & 1265 & 1356 \\
\hline $\begin{array}{l}\text { Including waiting patients on } 1 \text { January and in temporary } \\
\text { contraindication }\end{array}$ & 149 & 191 & 250 & 299 & 285 & 420 & 563 & 632 & 654 \\
\hline $\begin{array}{l}\% \text { of patients on temporary contraindication among the waiting patients } \\
\text { on } 1 \text { January }\end{array}$ & $22 \%$ & $24 \%$ & $27 \%$ & $32 \%$ & $26 \%$ & $33 \%$ & $43 \%$ & $50 \%$ & $48 \%$ \\
\hline - new entrants in the year & 1466 & 1580 & 1532 & 1724 & 1822 & 1786 & 1757 & 1824 & \\
\hline - died in the year & 136 & 170 & 137 & 183 & 208 & 214 & 184 & 162 & \\
\hline$\%$ of deaths among registered ${ }^{*}$ & $6.4 \%$ & $7.1 \%$ & $5.6 \%$ & $6.9 \%$ & $7.1 \%$ & $7 \%$ & $6.0 \%$ & $5.2 \%$ & \\
\hline - out of the waiting list & 146 & 192 & 222 & 215 & 212 & 262 & 251 & 249 & \\
\hline including those removed from the waiting list for worsening & 81 & 112 & 105 & 110 & 116 & 138 & 122 & 114 & \\
\hline Transplantations & 1047 & 1092 & 1164 & 1161 & 1241 & 1280 & 1355 & 1322 & \\
\hline - including living donor directed ones & 12 & 17 & 14 & 9 & 13 & 12 & 15 & 5 & \\
\hline - including domino living donor transplantation & 12 & 8 & 19 & 8 & 7 & 5 & 9 & 5 & \\
\hline - including transplants with donor dead after cardiac arrest MI-II & & 3 & 5 & 3 & 2 & 4 & 2 & 1 & \\
\hline - including transplants with donor dead after cardiac arrest MIII & & & & & & & 6 & 22 & \\
\hline Transplantations (per million inhabitants) & 16.4 & 16.9 & 17.9 & 17.7 & 18.9 & 19.3 & 20.4 & 19.8 & \\
\hline
\end{tabular}

* recipients on waiting list on 1 January of the current year + new registrants

donor organs was not possible for organizational or cultural reasons. Using a living donor graft presents several advantages: the programmed and controlled intervention at an optimum time for the recipient, the shorter cold ischemia time and the procurement of a living donor graft with predefined anatomical features and, more importantly, of optimal quality.

The main hindrance in the development of adult-adult LDLT is the risk of morbidity and mortality for donors, which raises legitimate ethical questions [8]. These ethical issues have been carefully considered and discussed by Singer et al. [9], who proposed the criteria by which donors and recipients should be selected. Because of the risks, this technique remains marginal, accounting only for $1 \%$ of all transplants performed in France currently (14 LDLT including 3 for adult recipients) (Table II). While there was only one center that performed adult LDLT in 1997 in the USA, this number has gradually increased to 38 centers in 2000. The number of adult-to-adult LDLT performed per year increased until the death of a liver donor in 2002 sparked a media furor that seriously compromised the pursuit of LDLT programs in the U.S. and significantly decreased the use of this procedure in the following years [10].

The aims of our study were to review the series dealing with morbidity and mortality in LDLT and to identify the strategies proposed in the literature for developing LDLT.

\section{SEARCH STRATEGY}

We conducted a systematic literature review in order to evaluate the morbidity and mortality of the donor in LDLT, and to assess the new strategies developed to increase LDLT practice.

A computerized search was made using the Medline database from January 2000 to 2017. Data sources were Englishlanguage reports on donor outcome after LDLT. Two searches were conducted: the MeSH terms "liver transplantation" and "morbidity" in combination with keyword "living donor liver transplantation" yielded 138 hits. The MeSH terms "liver transplantation" and "mortality" in combination with keyword "living donor liver transplantation" led to 267 hits. References of retrieved articles were cross-checked to identify additional reports. We excluded duplicate articles and obtained 382 articles about morbidity and/or mortality. Abstracts of relevant

Table II. Living donor liver transplantation activity in France since 1998. "Agence de Biomédecine"

\begin{tabular}{lcc}
\hline Year & \multicolumn{2}{c}{ Part of the liver removed } \\
\hline 1998 & Right & Left \\
\hline 1999 & 4 & 18 \\
2000 & 10 & 13 \\
2001 & 37 & 15 \\
2002 & 40 & 5 \\
2003 & 30 & 12 \\
2004 & 39 & 9 \\
2005 & 30 & 19 \\
2006 & 15 & 21 \\
2007 & 9 & 9 \\
2008 & 5 & 5 \\
2009 & 3 & 9 \\
$2010^{*}$ & 3 & 16 \\
2011 & 3 & 11 \\
2012 & 6 & 3 \\
2013 & 1 & 12 \\
2014 & 0 & 12 \\
\hline$*$ For & 5 &
\end{tabular}

${ }^{*}$ For medical reasons, two liver grafts from living donors could not be grafted; that is why the total number of collected living donors is not equal to the number of living donor transplants 
articles were reviewed independently using predetermined criteria, and appropriate articles were retrieved: abstracts with no relevance, no personal data, no information about donors or with already published data were excluded. For morbidity studies, we only included studies using the validated 5-tier Clavien grading [11]. Finally, we obtained 43 appropriate articles about morbidity, 15 about mortality and 6 regarding morbidity and mortality (Fig. 1). The study design and results are summarized in Tables III and IV.

\section{MORTALITY}

According to our search strategy, we identified 21 original articles regarding the mortality of living donors after hepatectomy (Fig. 1). These studies included 23 patients who died after hepatectomy for donation, between 1999 and 2017. Table III summarizes all living donor deaths after right living donor donation documented by at least one publication. The major cause of death was postoperative sepsis: $7 / 23$ (30\%) of donor deaths.

Although the mortality after right hepatectomy for donation is low ( 0.3 to $0.5 \%)$, death of a donor remains a tragedy for the families and transplant teams [2, 12, 13]. In 2006, the team of Paul Brousse Hospital published an opinion survey of health professionals (surgeons, physicians, nurses, aides and secretaries) on LDLT among adults from the same family [14]. In this series, the acceptable mortality rate for the donor was around $4 \%$, except among internists (0.7\%). These rates were all higher than the actual mortality rates reported in the literature (Table IV). The authors concluded that the psychological involvement of transplant teams, although very strong in these conditions, should not be an obstacle to the development of this technique. In 2006, Trotter et al. [15] collected data on all deaths after hepatectomy for donation. Of the 4,598 LDLT in the United States and Europe, 13 donor deaths and 1 permanent vegetative state were directly related to the surgery. Among the deceased donors, 9 had a right lobectomy, while a single donor had a left lobectomy. For 3 patients, the lobe removed was unspecified. In 2008, Ringe et al. [13] compiled all cases of death reported or known in the world (publications, conferences, communications, personal conversations). This study identified 33 liver donor deaths including 3 after rescue transplantation; only 12 deaths were published in detail. The risk of death was directly proportional to the quantity of parenchyma resected: this mortality rate was up to $0.5 \%$ after right hepatectomy and from 0.1 to $0.3 \%$ after left hepatectomy. These results were confirmed by a series focused on right hepatectomy for tumors. In 2007, Truant et al. [3] reported the results of 31 extended right hepatectomies in non-cirrhotic liver, and concluded that the ratio of remnant liver volume to body weight is more relevant than the ratio of remnant liver volume to total liver volume in predicting postoperative liver failure and death. Patients with an anticipated remnant liver volume of $<0.5 \%$ of the body weight were at considerable risk for postoperative mortality.

More recently, Muzaale et al. [2] reported the mortality rates and hepatocellular insufficiency after donation of part of the liver in the United States. Of the 4,111 LDLTs performed in the United States between 1994 and 2011, 7 donors died (4

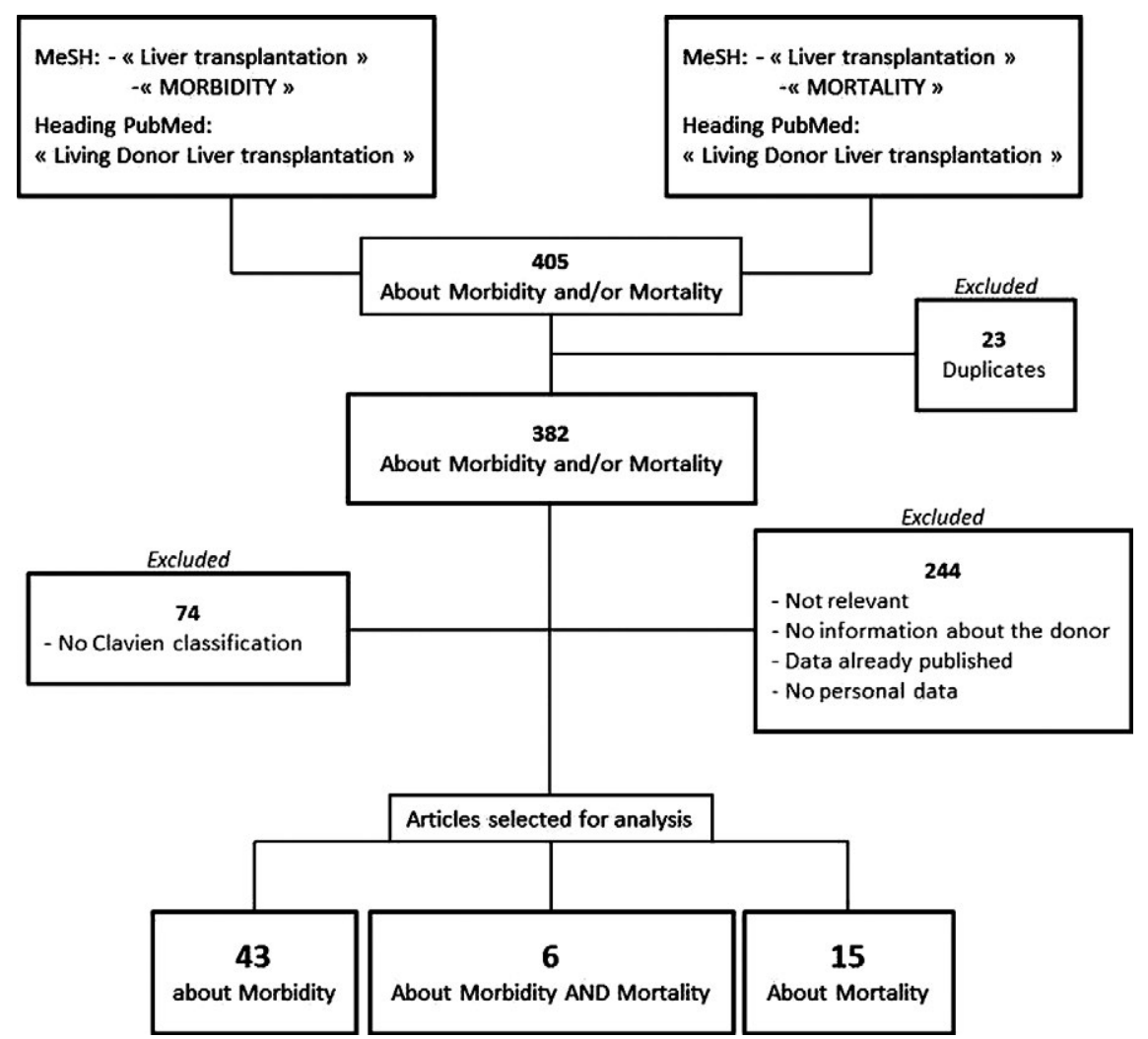

Fig. 1. The flow diagram depicting the flow of information through the different phases of the systematic review and describing the number of records identified, included and excluded, and the reasons for exclusions. 
Table III. Adult-adult liver transplantation mortality in the donor after right hepatectomy

\begin{tabular}{|c|c|c|c|c|}
\hline $\begin{array}{l}\text { Year of } \\
\text { death }\end{array}$ & Country and city & Description & $\begin{array}{l}\text { Period after } \\
\text { surgery }\end{array}$ & References \\
\hline 1999 & USA, Chapel Hill & A 41 year old man, died of acute pancreatitis and sepsis & 1 month & [15] \\
\hline 2000 & Germany, Lena & A 57 year old woman, died of sepsis and multiple organ failure & 21 days & {$[15,56]$} \\
\hline 2000 & France, Lyon & A 32 year old man, died of septic shock and multiple organ failure & 11 days & {$[15,56-58]$} \\
\hline 2000 & Germany, Essen & $\begin{array}{l}\text { A } 38 \text { year old man, died of liver failure and heart failure in } \\
\text { transplantation (patient with congenital generalized lipodystrophy } \\
\text { responsible for hepatic steatosis) }\end{array}$ & 32 days & {$[56,59]$} \\
\hline 2002 & USA, New York & $\begin{array}{l}\text { A } 57 \text { year old man, died of gas gangrene of the stomach and } \\
\text { toxin shock secondary to infection with Clostridium perfringens } \\
\text { (postoperative food contamination) }\end{array}$ & 3 days & {$[15,60]$} \\
\hline 2003 & Japan, Kyoto & $\begin{array}{l}\text { A } 46 \text { year old woman, died of liver failure secondary to a } \\
\text { small remnant liver ( } 26 \% \text { of the total liver) and nonalcoholic } \\
\text { steatohepatitis diagnosed postoperatively } \\
\text { Died despite a domino liver transplantation rescue }\end{array}$ & 9 months & {$[15,25,61,62]$} \\
\hline 2005 & Brazil, Curitiba & A 31 year old woman, died of subarachnoid hemorrhage & 7 days & {$[15,63]$} \\
\hline 2005 & China, Hong Kong & $\begin{array}{l}\text { A } 50 \text { year old woman, died of upper gastrointestinal bleeding and } \\
\text { air embolism secondary to a cavo-duodenal fistula }\end{array}$ & 10 weeks & {$[15,64]$} \\
\hline 2005 & Egypt, Cairo & An unknown age man, died of sepsis secondary to biliary fistula & 1 month & {$[14,64]$} \\
\hline 2005 & USA, Los Angeles & A 35 year old man who died of overdose & 23 months & {$[15,65]$} \\
\hline 2005 & USA & A 50 year old man, died by suicide at the gun, manic depression & 22 months & {$[15,37]$} \\
\hline 2005 & Singapore & A 39 year old man, died of heart attack & 4 days & {$[66]$} \\
\hline 2005 & Brazil, Parana & A 36-year-old female, died of cardiac arrhythmia & 2 days & [67] \\
\hline 2006 & USA, NYS & A 57-year-old man, died of respiratory failure and sepsis & 3 days & {$[68]$} \\
\hline 2007 & Turkey & A 35-year-old woman died from pulmonary embolism & 11 days & {$[69]$} \\
\hline 2007 & Egypt, Menoufiya & $\begin{array}{l}\text { A less than } 35 \text { year old man, died in the aftermath of intraoperative } \\
\text { bleeding (hemostasis defect of the right hepatic vein), complicated } \\
\text { by extensive thrombosis of the portal vein despite anticoagulation, } \\
\text { kidney failure, liver failure and thrombolysis }\end{array}$ & 12 days & [70] \\
\hline 2007 & France, Paris & $\begin{array}{l}\text { A } 47 \text { year old man, died of the rapid evolution of a myeloma IgG } \\
\text { Kappa undiagnosed preoperatively, complicated by pulmonary } \\
\text { embolism, thrombosis of the inferior vena cava, and multiple organ } \\
\text { failure secondary to pulmonary infection }\end{array}$ & 57 days & {$[71]$} \\
\hline 2008 & Egypt, Cairo & $\begin{array}{l}\text { A } 44 \text {-year-old man died of ongoing sepsis after uncontrolled biliary } \\
\text { leakage with peritonitis }\end{array}$ & 43 days & {$[72]$} \\
\hline 2010 & USA & $\begin{array}{l}\text { A } 50 \text { year old man who died of cardiovascular causes during } \\
\text { surgery }\end{array}$ & 0 day & {$[2]$} \\
\hline \multirow[t]{4}{*}{2010} & USA & A 30-year-old person died of respiratory failure & 4 days & {$[2]$} \\
\hline & Europe & A 64-year-old woman, died of infarctus of the papillary muscles & 32 days & {$[59]$} \\
\hline & North America & A 50-year-old man, died of self-inflicted gunshot & 22 months & {$[37]$} \\
\hline & North America & A 35-year-old man, died of a drug overdose & 23 months & [37] \\
\hline
\end{tabular}

Biliary complications: biliary strictures and fistulae; Vascular complications: portal vein thrombosis, hepatic veins thrombosis, deep vein thrombosis; Hepatic complications: Hepatic insufficiency, ascites, encephalopathy, hyperbilirubinemia.

after the removal of the right lobe, 1 of the left liver and 2 of the left lobe) and 4 other had liver failure in the postoperative period ( 3 of which required a transplantation).

Significant progress has been made worldwide since the first LDLT, but this technique remains at risk for the donor. We identified 23 deaths between 1999 and 2017, and this number is probably higher, taking into account unpublished donor mortality. Centers with unreported deaths should submit these outcomes to the liver transplantation community to provide a better estimate of donor death rate. Furthermore, despite our research we have not found any recorded donor death after 2010 , which raises the problem of inhomogeneous publication of worldwide data.

\section{MORBIDITY}

Removal of the right liver from a healthy donor is subject to significant morbidity. Indeed, the reported morbidity varied from $10 \%$ to $78.3 \%$ (Table IV).

In 2002, Beavers et al. [16] compiled all outcome studies after donation of the right liver. Of the 211 publications dealing with this subject, the authors reported 12 studies with detailed results on postoperative complications. The overall morbidity rate was $31 \%$ (54 events in 174 donors) in this report [16]. However, the definition of complications is not standardized between different studies, which may lead to an underestimation of morbidity. In 2007, Yi et al. [17] reported 
Table IV. Evaluation of donor morbidity for living donor liver transplantation according to the Clavien score [8]

\begin{tabular}{|c|c|c|c|c|c|c|c|c|}
\hline $\begin{array}{l}\text { First author and } \\
\text { year of publication } \\
\text { [Ref }]\end{array}$ & Country & $\begin{array}{c}\text { Transplantation } \\
\text { period }\end{array}$ & $\begin{array}{c}\text { Living donor } \\
\text { (except domino) }\end{array}$ & Morbidity & $\begin{array}{l}\text { Proportion of } \\
\text { complications } \\
\geq \text { Clavien } \\
\text { grade III }\end{array}$ & $\begin{array}{c}\text { Biliary } \\
\text { complications }\end{array}$ & $\begin{array}{c}\text { Vascular } \\
\text { complications }\end{array}$ & $\begin{array}{c}\text { Hepatic } \\
\text { complications }\end{array}$ \\
\hline S.A. Shah, 2006 [1] & Canada & 2000 to 2005 & 101 & $37 \%$ & $20 \%$ & $3 \%$ & $6 \%$ & $0 \%$ \\
\hline B. Gali, 2007 [72[ & USA & 2000 to 2005 & 40 & $35 \%$ & $64 \%$ & $15 \%$ & $4 \%$ & $0 \%$ \\
\hline $\begin{array}{l}\text { S.C. Chan, } 2007 \\
{[63]}\end{array}$ & China & 1996 to 2005 & 200 & $20 \%$ & $22 \%$ & $2 \%$ & $1 \%$ & $0.5 \%$ \\
\hline N. J. Yi, 2007 [17] & Korea & 2002 to 2004 & 83 & $78 \%$ & $1 \%$ & $11 \%$ & $0.3 \%$ & $5 \%$ \\
\hline $\begin{array}{l}\text { S. Gruttadauria, } \\
2008[73]\end{array}$ & Italy & 2002 to 2007 & 75 & $31 \%$ & $65 \%$ & $9 \%$ & $3 \%$ & $4 \%$ \\
\hline $\begin{array}{l}\text { J. W. Marsh, } 2009 \\
\text { [24] }\end{array}$ & USA & 2003 to 2006 & 121 & $20 \%$ & $54 \%$ & $6 \%$ & $2 \%$ & $0.8 \%$ \\
\hline B. Liu, 2009 [74] & China & 2002 to 2008 & 160 & $33 \%$ & $8 \%$ & NP & NP & NP \\
\hline T. Lida, 2010 [25] & Japan & 1990 to 2007 & 500 & $44 \%$ & $17 \%$ & $12 \%$ & $0.2 \%$ & $2 \%$ \\
\hline $\begin{array}{l}\text { A. Azzam, } 2010 \\
{[60]}\end{array}$ & Japan & 1998 to 2003 & 311 & $33 \%$ & $35 \%$ & $13 \%$ & $0.3 \%$ & $1 \%$ \\
\hline SJ. Kim, 2012 [75] & & 1999 to 2011 & 500 & $22 \%$ & $5 \%$ & $11 \%$ & $4 \%$ & $9 \%$ \\
\hline K. W. Li, 2010 [76] & China & 2002 to 2009 & 143 & $10 \%$ & $40 \%$ & $2 \%$ & $2 \%$ & $0.7 \%$ \\
\hline $\begin{array}{l}\text { A. Taketomi, } 2010 \\
{[77]}\end{array}$ & Japan & 1996 to 2009 & 343 & $27 \%$ & $7 \%$ & $4 \%$ & NP & NP \\
\hline $\begin{array}{l}\text { M. El-Meteini, } 2010 \\
{[71]}\end{array}$ & Egypt & 2001 to 2008 & 207 & & $7 \%$ & $13.04 \%$ & NP & NP \\
\hline $\begin{array}{l}\text { D. Azoulay, } 2011 \\
{[23]}\end{array}$ & France & 2000 to 2009 & 91 & $47 \%$ & $37 \%$ & $14 \%$ & $2 \%$ & $8 \%$ \\
\hline D. Yuan, 2011 [78] & China & 2005 to 2008 & 132 & $71 \%$ & $8 \%$ & NP & NP & NP \\
\hline $\begin{array}{l}\text { O. Yaprak, } 2012 \\
\text { [79] }\end{array}$ & Turkey & 2003 to 2011 & 262 & $30 \%$ & $26 \%{ }^{*}$ & NP & NP & NP \\
\hline Z. R. Shi, 2012 [80] & China & 2001 to 2009 & 151 & $33 \%$ & $26 \%$ & $10 \%$ & $3 \%$ & $6 \%$ \\
\hline $\begin{array}{l}\text { H.R. Yang, } 2012 \\
{[81]}\end{array}$ & China Taiwan & 2005 to 2011 & 202 & $23 \%$ & $15 \%$ & NP & NP & NP \\
\hline M. Shin, 2012 [82] & & 1996 to 2010 & 827 & $10 \%$ & $18 \%$ & $\mathrm{NP}$ & NP & NP \\
\hline T. Salah, 2012 [83] & Egypt & 2004 to 2010 & 100 & $38 \%$ & NP & NP & NP & NP \\
\hline $\begin{array}{l}\text { MM. Abecassis, } \\
2012[88]\end{array}$ & USA & 1998 to 2010 & 760 & $40 \%$ & $0.68 \%$ & $9 \%$ & $1 \%$ & $3 \%$ \\
\hline $\begin{array}{l}\text { M. Facciuto, } 2013 \\
{[85]}\end{array}$ & USA & 1999 to 2010 & 137 & $33 \%$ & $24 \%$ & $4 \%$ & $2 \%$ & $24 \%$ \\
\hline $\begin{array}{l}\text { M. Wadhawan, } \\
2013 \text { [86] }\end{array}$ & India & 2006 to 2010 & 338 & $\mathrm{NP}$ & $80 \% * *$ & $19 \%$ & NP & NP \\
\hline J. Y. Lei, 2013 [87] & China & 2002 to 2010 & 210 & $29 \%$ & $27 \%$ & $3 \%$ & $2 \%$ & $26 \%^{* * *}$ \\
\hline S. Usta, 2013 [88] & Turkey & 2006 to 2012 & 60 & $20 \%$ & $25 \%$ & $12 \%$ & NP & $2 \%$ \\
\hline D. Ozgor, 2012 [89] & Turkey & 2007 to 2011 & 500 & $19 \%$ & $18 \%$ & $11 \%$ & $7 \%$ & NP \\
\hline $\begin{array}{l}\text { A. Lauterio, } 2013 \\
{[90]}\end{array}$ & Italy & 2001 to 2012 & 80 & $32 \%$ & $9 \%$ & NP & NP & $0 \%$ \\
\hline M. Ozsoy, 2014 [91] & Turkey & 2004 to 2009 & 272 & $41 \%$ & $3 \%$ & $11 \%$ & $\mathrm{NP}$ & $\mathrm{NP}$ \\
\hline $\begin{array}{l}\text { A. Dirican, } 2015 \\
{[92]}\end{array}$ & Turkey & 2006 to 2012 & 593 & $17 \%$ & $5 \%$ & $9 \%$ & NP & NP \\
\hline Z. Sun, 2015 [93] & China & 2006 to 2014 & 152 & $40 \%$ & $8 \%$ & NP & NP & NP \\
\hline F. Rossler, 2016 [27] & world & 2004 to 2014 & 4206 & $13 \%$ & $4 \%$ & NP & NP & NP \\
\hline J.G. Lee, 2017 [28] & Korea & 2014 to 2015 & 832 & $9 \%$ & $1.9 \%$ & $1.7 \%$ & NP & NP \\
\hline
\end{tabular}

NP: unspecified data; ${ }^{*}$ Major complications reported as it is not possible to be certain according to data from the article that this figure covers all the classified complications Clavien III and more. ${ }^{* *}$ Biliary complications only. ${ }^{* *}$ Hyperbilirubinemia $\geq 86.2 \mu \mathrm{mol} / \mathrm{L}$ during the first postoperative week

an overall morbidity of $78.3 \%$ (65 events in 83 donors) after a prospective and comprehensive collection of complications after the donation of the right liver. The majority of complications (77\%) were categorized as Clavien Grade I complications [11] 
The morbidity rate was correlated to the amount of liver tissue removed. The reports of the majority of transplant centers in Europe, Asia and the United States indicated that the rate of post-operative complications is higher after a right hepatectomy [18] than after a left hepatectomy especially regarding biliary leakage [16, 19-21].

Moreover, some series showed that right hepatectomy for donation in high volume centers retains a significant morbidity [22]. In 2011, Azoulay et al. [23] reported the largest European single center series of hepatectomy for donation straight and a comprehensive assessment of complications classified according to the Clavien score [11]. In this series, less than half of the 91 donors, operated between 2000 and 2009, had a complication and a third of these were major complications $(\geq$ grade III). It is interesting to note that in this series, as well as in other high-volume centers in Asia and the United States, there was no improvement in overall morbidity over time [2, 23-25].

Recently, Belghiti et al. [26] reported the results of a casecontrol study comparing the effects of right hepatectomy in a living donor with those of a right hepatectomy for benign tumors that may explain this stable morbidity. The authors underlined that the complication rate was superior in a right hepatectomy for donation than for benign tumors. They concluded that living donor right hepatectomy caused a more severe loss of liver volume than right hepatectomy for benign tumors and that the liver regeneration effort remaining after hepatectomy was so important that it could have explained a greater vulnerability to postoperative complications. To measure and define the best achievable outcome after major hepatectomy, Rossler et al. [27] in 2016 proposed the analysis of a multicentric international series of 5202 hemi-hepatectomies from living donor. Indeed, analysis in living liver donors, with safety as the highest priority, offers the opportunity to define outcome benchmarks as the best possible results. Endpoints included postoperative morbidity measured by the ClavienDindo classification, the Comprehensive Complication Index (CCI), and liver failure according to different definitions. They reported that $12 \%$ of patients developed at least 1 complication: of these, $3.8 \%$ were major events (grade III, including 1 death), mostly related to biliary/bleeding events, and were twice higher after right hepatectomy. Lee et al. [28] recently reviewed prospectively collected data from the Korean Organ Transplantation Registry of all 832 live liver donors who underwent procedures between April 2014 and December 2015. They reported no deaths after living liver donation and overall, biliary and major complication (grade $\geq$ III) rates were $9.3 \%, 1.7 \%$ and $1.9 \%$, respectively. Based on this literature review, the right liver removal in the living donor was burdened with significant morbidity even in experienced surgical teams [28]. The mortality of this procedure (which remains a major hepatic resection) cannot be reduced below $0.3 \%$ [2]. The decrease in morbidity and mortality in LDLT donors remains an important issue in the development of this technique in order to meet ethical requirements.

\section{QUALITY OF LIFE}

Beyond morbidity and mortality, the quality of life (QoL) of the donor after donation must also be considered. Indeed, living donors achieve no medical benefits and are exposed to the risk of major complications. Surprisingly, several studies showed that the QoL of donors was similar or even better than the reference population before donation [29]. The Physical Component Score decreased immediately after donation, then returned to baseline within 6 to 12 months, while the Mental Component Score remained comparable to that of normative population throughout the procedure [30]. In a study involving 19 living donors, Parolin et al. [31] showed that the donor's relationship to the recipient and to their families was improved after donation in all cases. Moreover, Bhatti et al. [32] showed that acceptable post-donation QoL was achieved and no significant difference in scores was observed between donors with and without surgical complications. This report is similar with those of Beavers et al. [33], who reported that regardless of recipient outcome, $100 \%$ of donors would donate again and of Chang et al. [34] who reported that $87 \%$ of donors showed a willingness to re-donate. In contrast, Kousoulas et al. [35] reported that donors did not regret their decision to donate but development of postoperative donor complications and the postoperative recipient mortality had a negative effect on the Health-related QoL of donors. Evaluation of anxiety and depression 3 months after donation found no difference between donors and controls [36]. Psychiatric complications were found in $4.1 \%$ of donors in an Adult to Adult living donor liver transplantation study [37]. Among the 23 donor deaths described in the literature, 4 were due to suicide, raising questions about the donors QoL as well as their psychological follow-up after donation $[15,37]$.

\section{HOW TO REDUCE MORBIDITY AND MORTALITY IN LIVING DONORS?}

To balance both a reduction of the risk for donors and to improve the outcome of the recipient, many strategies have been proposed. We have divided these different strategies into two groups: those aimed at reducing the amount of parenchyma harvested in the donor and those aimed at increasing the donor future remnant liver before the hepatectomy.

\section{Reducing the amount of parenchyma harvested in the donor}

These strategies comprised the limitation of the amount of parenchyma harvested in the donor and the control of the small for size syndrome (SFSS) risk in the recipient.

\section{Operative strategies}

To avoid the right lobe donor risks, some teams started to use left lobe donation in adult patients. This procedure was first described by Hashikura in 1994 [6]. However, after the first successful graft, Tanaka et al. [38] reported in their early series of left lobe (LL) LDLT an $82.1 \%$ survival in patients with a graft to recipient weight ratio $>0.8$ but only $54.5 \%$ in those with a ratio $<0.8$. Furthermore, Kiuchi et al. [39] revealed inferior graft survival rates for smaller grafts which dropped off the LL graft development. Soejima et al. [40, 41] performed large single center studies which showed that the outcomes of LL LDLT were comparable with those of RL LDLT, although SFSS occurred more often in LL LDLT [2, 3]. To manage SFSS, they developed a specific approach to avoid excessive portal flow 
in the graft using hemi porto-caval shunt and splenectomy. They concluded that LL grafts should be considered as the first procedure except for patients with MELD score $>30$.

In order to deal with SFSS, dual graft LDLT was also introduced to obtain combined graft sufficiency. Xu et al. [42] reported 367 patients worldwide in 2015 and concluded that dual graft LDLT should be prudently performed in selected cases by surgeons of proven expertise when a single donation is unacceptable and a second living donor is available. However, the decision-making criteria need to be standardized and ethical concerns about involving a second living donor need to be addressed [42].

\section{Pharmacological treatment of SFSS}

A variety of experimental pharmacological treatment strategies have been described for the prevention of SFSS, based on the attenuation of portal shear stress and the enhancement of liver regeneration. The modulation of prostaglandin E1, nitric oxide, endothelin receptor $\mathrm{A}$, adenosine $2 \mathrm{~A}$ receptor, has been tested in animal models [43]. In 2016, Mohkam et al. [44] demonstrated the preventive effect of somatostatin by decreasing portal vein flow in a porcine model of SFSS [44]. Similar results were demonstrated in $90 \%$ of hepatectomized murine models using octreotide infusion [45]. Treatment of SFSS by somatostatin and propranolol has also been clinically tested and resulted in a favorable outcome [46].

Increasing the donor future remnant liver before the hepatectomy

\section{Pharmacological preconditioning}

In 2005, Malik et al. [47] proposed in an experimental study the administration of thyroid hormones (triiodothyronine, T3) to the donor rats, 10 days before hepatectomy (70\% and $90 \%$ hepatectomy). The authors reported that the injection of T3 (bolus $4 \mathrm{mg} / \mathrm{kg}$ ) in rats was responsible for a trigger of hepatic regeneration and increased liver weight/body weight on day 10 associated with an increase in total liver volume. The $70 \%$ hepatectomy, 10 days after the preconditioning (T3), left in place a remnant liver volume larger than in non-pre-conditioned animals. After $90 \%$ hepatectomy, the preconditioned animals had better survival than nonpreconditioned (57\% vs. $14 \%$ ). However, the T3 injected doses were almost 2000 times the maximum dose in humans treated for thyroid insufficiency [48]. Despite these interesting results in terms of liver regeneration, it seems difficult to apply this preconditioning to humans considering the consequences, including cardiac, of an overdose of thyroid hormones.

\section{Portal flow modulation in donors}

Ischemic preconditioning by clamping the right pedicle for 10 minutes before living donation has been proposed to decrease the ischemia-reperfusion injury $[49,50]$. Despite the involvement of anti-apoptotic molecular mechanisms, the authors did not report any clinical benefit in the donor or recipient.

Portal vein embolization is used in liver tumor treatment prior to major hepatectomy. The aim of this technique is to induce the atrophy of the ipsilateral liver and thus the hypertrophy of the future remnant liver before hepatectomy. Based on these results, some teams have developed reversible portal vein embolization to avoid liver atrophy [51-53].
Nevertheless, reversible portal vein embolization failed to reduce liver atrophy and therefore, this technique cannot be used for living donor liver preconditioning [53].

Khan et al. [54] studied the effects of partial portal vein ligation 8 weeks prior to hepatectomy on a murine model of partial hepatectomy. They observed that partial portal vein ligation prior to hepatectomy did not impair hepatic regeneration capacity, compared to sham animals.

Gregoire et al. recently identified that $20 \%$ stenosis of the portal vein of a hemi-liver in pigs induced a contralateral hypertrophy without atrophy of the ipsilateral liver [55]. This procedure might be an effective donor preconditioning in order to achieve a larger remnant liver in living donor without altering the future graft. Indeed, the $20 \%$ stenosis of the portal vein of a hemi-liver triggered the liver regeneration in the contralateral lobe (the future remnant liver of the donor) with cell proliferation equivalent to that observed after ligation or embolization of the portal vein.

\section{CONCLUSIONS}

Morbidity, mortality and donor QoL remain a major hindrance to the development of LDLT.

Donor morbidity and mortality are inevitable given the ultra-major nature of the donor operation, which is why the most serious ethical concerns in LDLT focus on the risks to the donor and relate to the principle of 'do no harm'. However, the state of research on the preconditioning of the donor allows an improvement in these parameters to be considered in the future, including donor preconditioning techniques (absorbable portal embolization, portal stenosis) and the use of the left liver associated with portal flow modulation in the recipient (portal banding).

Moreover, these techniques could represent a hope for countries in which LDLT is the only source of graft for organizational or cultural reasons.

Conflicts of interest: The authors declare no conflicts of interest.

Authors' contribution: P.B., G.H., S.C. and A.P. collected and analyzed data; P.B. and G.H. wrote the manuscript; D.A. analyzed data, designed study and reviewed the manuscript; E.G. designed the study, collected data, reviewed the manuscript.

Acknowledgements: The authors gratefully acknowledge the assistance of Prof. Y.P. Le Treut and Prof. J. Hardwigsen for their thoughtful comments about the manuscript.

\section{REFERENCES}

1. Shah SA, Levy GA, Adcock LD, Gallagher G, Grant DR. Adult-to-adult living donor liver transplantation. Can J Gastroenterol 2006;20:339-343.

2. Muzaale AD, Dagher NN, Montgomery RA, Taranto SE, McBride MA, Segev DL. Estimates of early death, acute liver failure, and long-term mortality among live liver donors. Gastroenterology 2012;142:273-280. doi:10.1053/j.gastro.2011.11.015

3. Truant S, Oberlin O, Sergent G, et al. Remnant liver volume to body weight ratio $\geq 0.5 \%$ : A new cut-off to estimate postoperative risks after 
extended resection in noncirrhotic liver. J Am Coll Surg 2007;204:22-33 doi:10.1016/j.jamcollsurg.2006.09.007

4. Raia S, Nery JR, Mies S. Liver transplantation from live donors. Lancet 1989;2:497. doi:10.1016/S0140-6736(89)92101-6

5. Strong RW, Lynch SV, Ong TH, Matsunami H, Koido Y, Balderson G. Successful liver transplantation from a living donor to her son. N Engl J Med 1990;322:1505-1507. doi:10.1056/NEJM199005243222106

6. Hashikura Y, Makuuchi M, Kawasaki S, et al. Successful living-related partial liver transplantation to an adult patient. Lancet 1994;343:12331234. doi:10.1016/S0140-6736(94)92450-3

7. Lo CM, Fan ST, Liu CL, et al. Adult-to-adult living donor liver transplantation using extended right lobe grafts. Ann Surg 1997;226:261269.

8. Pruvot FR. Adult living donor liver transplantation: why the scepticism? Gastroenterol Clin Biol 2002;26:1087-1090.

9. Singer PA, Siegler M, Whitington PF, et al. Ethics of liver transplantation with living donors. N Engl J Med 1989;321:620-622. doi:10.1056/ NEJM198908313210919

10. Kim PT, Testa G. Living donor liver transplantation in the USA. Hepatobiliary Surg Nutr 2016;5:133-140. doi:10.3978/j.issn.2304-3881.2015.06.01

11. Dindo D, Demartines N, Clavien PA. Classification of surgical complications: a new proposal with evaluation in a cohort of 6336 patients and results of a survey. Ann Surg 2004;240:205-213. doi:10.1097/01.sla.0000133083.54934.ae

12. Kim SH, Lee SD, Kim YK, Park SJ. Pushing the frontiers of living donor right hepatectomy. World J Gastroenterol 2014;20: 18061-18069. doi:10.3748/wjg.v20.i48.18061

13. Ringe B, Strong RW. The dilemma of living liver donor death: to report or not to report? Transplantation 2008;85:790-793. doi:10.1097/ TP.0b013e318167345e

14. Castaing D, Azoulay D, Danet C, et al. Medical community preferences concerning adult living related donor liver transplantation. Gastroenterol Clin Biol 2006;30:183-187.

15. Trotter JF, Adam R, Lo CM, Kenison J. Documented Deaths of Hepatic Lobe Donors for Living Donor Liver Transplantation. Liver Transpl 2006;12:1485-1488. doi:10.1002/lt.20875

16. Beavers KL, Sandler RS, Shrestha R. Donor morbidity associated with right lobectomy for living donor liver transplantation to adult recipients: A systematic review. Liver Transpl 2002;8:110-117. doi:10.1053/ jlts.2002.31315

17. Yi NJ, Suh KS, Cho JY, et al. Three-quarters of right liver donors experienced postoperative complications. Liver Transpl 2007;13:797806. doi: $10.1002 / 1$ t.21030

18. Strasberg SM. Nomenclature of hepatic anatomy and resections: A review of the Brisbane 2000 system. J Hepatobiliary Pancreat Surg 2005;12:351-355. doi:10.1007/s00534-005-0999-7

19. Ghobrial RM, Freise CE, Trotter JF, et al. Donor Morbidity After Living Donation for Liver Transplantation. Gastroenterology 2008;135:468476. doi:10.1053/j.gastro.2008.04.018

20. Shio S, Yazumi S, Ogawa K, et al. Biliary complications in donors for living donor liver transplantation. Am J Gastroenterol 2008;103:13931398. doi:10.1111/j.1572-0241.2008.01786.x

21. Uchiyama $\mathrm{H}$, Shirabe $\mathrm{K}$, Nakagawara $\mathrm{H}$, et al. Revisiting the safety of living liver donors by reassessing 441 donor hepatectomies: Is a larger hepatectomy complication-prone? Am J Transplant 2014;14:367-374. doi:10.1111/ajt.12559

22. Hwang S, Lee SG, Lee YJ, et al. Lessons learned from 1,000 living donor liver transplantations in a single center: How to make living donations safe. Liver Transpl 2006;12:920-927. doi:10.1002/1t.20734
23. Azoulay D, Bhangui P, Andreani P, et al. Short- and long-term donor morbidity in right lobe living donor liver transplantation: 91 consecutive cases in a European Center. Am J Transplant 2011;11:101-110. doi:10.1111/j.1600-6143.2010.03284.x

24. Marsh JW, Gray E, Ness R, Starzl TE. Complications of right lobe living donor liver transplantation. J Hepatol 2009;51:715-724. doi:10.1016/j. jhep.2009.04.023

25. Iida T, Ogura Y, Oike F, et al. Surgery-related morbidity in living donors for liver transplantation. Transplantation 2010;89:1276-1282. doi:10.1097/TP.0b013e3181d66c55

26. Belghiti J, Liddo G, Raut V, et al. "Inherent limitations" in donors: control matched study of consequences following a right hepatectomy for living donation and benign liver lesions. Ann Surg 2012;255:528-533. doi:10.1097/SLA.0b013e3182472152

27. Rössler F, Sapisochin G, Song G, et al. Defining Benchmarks for Major Liver Surgery: A multicenter Analysis of 5202 Living Liver Donors. Ann Surg 2016;264:492-500. doi:10.1097/SLA.0000000000001849

28. Lee JG, Lee KW, Kwon CHD, et al. Donor safety in living donor liver transplantation: The Korean Organ Transplantation Registry study. Liver Transpl 2017;23:999-1006. doi:10.1002/1t.24778

29. Walter M, Dammann G, Papachristou C, et al. Quality of life of living donors before and after living donor liver transplantation. Transplant Proc 2003;35:2961-2963. doi:10.1016/j.transproceed.2003.10.048

30. Xu DW, Long XD, Xia Q. A review of life quality in living donors after liver transplantation. Int J Clin Exp Med 2015;8:20-26.

31. Parolin MB, Lazzaretti CT, Lima JH, Freitas AC, Matias JE, Coelho JC Donor quality of life after living donor liver transplantation. Transplant Proc 2004;36:912-913. doi:10.1016/j.transproceed.2004.03.098

32. Bhatti AB, Zia H, Dar FS, et al. Quality of Life After Living Donor Hepatectomy for Liver Transplantation. World J Surg 2015;39:23002305. doi:10.1007/s00268-015-3086-5

33. Beavers KL, Sandler RS, Fair JH, Johnson MW, Shrestha R. The living donor experience: donor health assessment and outcomes after living donor liver transplantation. Liver Transpl 2001;7:943-947. doi:10.1053/ jlts.2001.28443

34. Chang YM, Chung KP, Chen TW, Hsieh CB. Intention of donors to redonate livers after living donor liver transplantation in a liver transplant center in Asia. Ann Transplant 2014;19:421-426. doi:10.12659/ AOT.890821

35. Kousoulas L, Emmanouilidis N, Klempnauer J, Lehner F. Livingdonor liver transplantation: Impact on Donor's health-related quality of life. Transplant Proc 2011;43:3584-3587. doi:10.1016/j. transproceed.2011.10.038

36. Sevmis S, Karakayali H, Karakayali F, Savas NA, Akkoc H, Haberal M. Postsurgical complications in living-related liver donors. Transplant Proc. 2008;40:245-247. doi:10.1016/j.transproceed.2007.11.009

37. Trotter JF, Hill-Callahan MM, Gillespie BW, et al. Severe psychiatric problems in right hepatic lobe donors for living donor liver transplantation. Transplantation 2007;83:1506-1508. doi:10.1097/01 tp.0000263343.21714.3b

38. Tanaka K, Ogura Y. "Small-for-size graft" and "small-for-size syndrome" in living donor liver transplantation. Yonsei Med J 2004;45:1089-1094 doi:10.3349/ymj.2004.45.6.1089

39. Kiuchi T, Kasahara M, Uryuhara K, et al. Impact of graft size mismatching on graft prognosis in liver transplantation from living donors. Transplantation 1999;67:321-327.

40. Soejima Y, Shirabe K, Taketomi A, et al. Left lobe living donor liver transplantation in adults. Am J Transplant 2012;12:1877-1885. doi:10.1111/j.1600-6143.2012.04022.x 
41. Soejima Y, Taketomi A, Yoshizumi T, et al. Feasibility of left lobe living donor liver transplantation between adults: An 8-year, singlecenter experience of 107 cases. Am J Transplant 2006;6:1004-1011. doi:10.1111/j.1600-6143.2006.01284.x

42. Xu Y, Chen $\mathrm{H}$, Yeh $\mathrm{H}$, Wang $\mathrm{H}$, Leng J, Dong J. Living donor liver transplantation using dual grafts: Experience and lessons learned from cases worldwide. Liver Transpl 2015;21:1438-1448. doi:10.1002/lt.24315

43. Goldaracena N, Echeverri J, Selzner M. Small-for-size syndrome in live donor liver transplantation-Pathways of injury and therapeutic strategies. Clin Transplant 2017;31:e12885. doi:10.1111/ctr.12885

44. Mohkam K, Darnis B, Schmitt Z, Duperret S, Ducerf C, Mabrut JY. Successful modulation of portal inflow by somatostatin in a porcine model of small-for-size syndrome. Am J Surg 2016;212:321-326. doi:10.1016/j.amjsurg.2016.01.043

45. Du Z, Zhou Y, Lu X, et al. Octreotide prevents liver failure through upregulating 5 '-methylthioadenosine in extended hepatectomized rats. Liver Int 2016;36:212-222. doi:10.1111/liv.12863

46. Ozden I, Kara M, Pinarbasi B, et al. Somatostatin and propranolol to treat small-for-size syndrome that occurred despite splenic artery ligation. Exp Clin Transplant 2007;5:686-689.

47. Malik R, Habib M, Tootle R, Hodgson H. Exogenous thyroid hormone induces liver enlargement, whilst maintaining regenerative potential - A study relevant to donor preconditioning. Am J Transplant 2005;5:18011807. doi:10.1111/j.1600-6143.2005.00949.x

48. Hamilton MA, Stevenson LW, Fonarow GC, et al. Safety and hemodynamic effects of intravenous triiodothyronine in advanced congestive heart failure. Am J Cardiol 1998;81:443-447. doi:10.1016/ S0002-9149(97)00950-8

49. Andreani P, Hoti E, de la Serna S, et al. Ischaemic preconditioning of the graft in adult living related right lobe liver transplantation: impact on ischaemia-reperfusion injury and clinical relevance. HPB (Oxford) 2010;12:439-446. doi:10.1111/j.1477-2574.2010.00194.x

50. Testa G, Angelova V, Laricchia-Robbio L, et al. Unilateral ischemic preconditioning and heterologous preconditioning in living donor liver transplantation. Clin Transplant 2010;24:334-340. doi:10.1111/j.1399. 0012.2009.01075.x

51. Lesurtel M, Belghiti J. Temporary portal vein embolization as a starter of liver regeneration. J Hepatol 2008;49:313-315. doi:10.1016/j. jhep.2008.06.004

52. Dagher I, Nguyen TH, Groyer-Picard MT, et al. Efficient hepatocyte engraftment and long-term transgene expression after reversible portal embolization in nonhuman primates. Hepatology 2009;49:950-959. doi:10.1002/hep.22739

53. Lainas $\mathrm{P}$, Boudechiche L, Osorio A, et al. Liver regeneration and recanalization time course following reversible portal vein embolization. J Hepatol 2008;49:354-362. doi:10.1016/j.jhep.2008.01.034

54. Kahn D, Kajani M, Zeng Q, et al. Effect of partial portal vein ligation on hepatic regeneration. J Invest Surg 1988;1:267-276.

55. Gregoire E, Brige P, Barbier L, et al. Minimal portal vein stenosis is a promising preconditioning in living donor liver transplantation in porcine model. J Hepatol 2014;61:59-66. doi:10.1016/j.jhep.2014.02.034

56. Adam R, McMaster P, O'Grady JG, et al. Evolution of liver transplantation in Europe: report of the European Liver Transplant Registry. Liver Transpl 2003;9:1231-1243. doi:10.1016/j. lts.2003.09.018

57. Boudjema K. Transplantation hépatique à partir d'un donneur vivant Gastroenterol Clin Biol 2001;25:771-772.

58. Boillot O, Belghiti J, Azoulay D, Gugenheim J, Soubrane O, Cherqui D. Initial French experience in adult-to-adult living donor liver transplantation. Transplant Proc 2003;35:962-963. doi:10.1016/S00411345(03)00185-4

59. Malagó M, Testa G, Frilling A, et al. Right living donor liver transplantation an option for adult patients: single institution experience with 74 patients. Ann Surg 2003;238:853-862. doi:10.1097/01.sla.0000098619.71694.74

60. Miller C, Florman S, Kim-Schluger L, et al. Fulminant and fatal gas gangrene of the stomach in a healthy live liver donor. Liver Transpl 2004;10:1315-3119. doi:10.1002/lt.20227

61. Azzam A, Uryuhara K, Taka I, Takada Y, Egawa H, Tanaka K. Analysis of complications in hepatic right lobe living donors. Ann Saudi Med 2010;30:18-24.

62. Akabayashi A, Slingsby B, Fujita M. The first donor death after livingrelated liver transplantation in Japan. Transplantation 2004;77:634. doi:10.1097/01.TP.0000115342.98226.7C

63. Wiederkehr JC, Pereira JC, Ekermann M, et al. Results of 132 hepatectomies for living donor liver transplantation: report of one death. Transplant Proc 2005;37:1079-1080. doi:10.1016/j. transproceed.2004.12.221

64. Chan SC, Fan ST, Lo CM, Liu CL, Wong J. Toward current standards of donor right hepatectomy for adult-to-adult live donor liver transplantation through the experience of 200 cases. Ann Surg 2007;245:110-117. doi:10.1097/01.sla.0000225085.82193.08

65. Khalaf H, El-Meteini M, El-Sefi T, et al. Evolution of living donor liver transplantation in Egypt. Saudi Med J 2005;26:1394-1397.

66. Polido W Jr, Hoe LK, Siang NK, Chah TK. Acute Myocardial Infarction After Live Donor Liver Surgery. Liver Transpl 2007;13:154-156. doi:10.1002/lt.21002

67. Coelho JC, De Freitas AC, Matias JE, et al. Donor complications including the report of one death in right-lobe living-donor liver transplantation. Dig Surg 2007;24:191-196. doi:10.1159/000102898

68. Patel S, Orloff M, Tsoulfas G, et al. Living-donor liver transplantation in the United States: Identifying donors at risk for perioperative complications. Am J Transplant 2007;70:2344-2349. doi:10.1111/j.16006143.2007.01938.x

69. Ozkardesler S, Ozzeybek D, Alaygut E, et al. Anesthesia-related complications in living liver donors: The experience from one center and the reporting of one death. Am J Transplant 2008;8:2106-2110. doi:10.1111/j.1600-6143.2008.02367.x

70. Kamel E, Abdullah M, Hassanin A, et al. Live donor hepatectomy for liver transplantation in Egypt: Lessons learned. Saudi J Anaesth 2012;6:234-241. doi:10.4103/1658-354X.101214

71. Melloul E, Dondero F, Paugam-Burtz C, Bouadma L, Arnulf B, Belghiti J. Living liver donor death related to complications of myeloma. Liver Transpl 2009;15:326-329. doi:10.1002/1t.21685

72. El-Meteini M, Hamza A, Abdalaal A, et al. Biliary complications including single-donor mortality: Experience of 207 adult-to-adult living donor liver transplantations with right liver grafts. HPB (Oxford) 2010;12:109-114. doi:10.1111/j.1477-2574.2009.00142.x

73. Gali B, Findlay J, Plevak DJ, Rosen CB, Dierkhising R, Nagorney DM. Right hepatectomy for living liver donation vs right hepatectomy for disease: intraoperative and immediate postoperative comparison. Arch Surg 2007;142:467-471. doi:10.1001/archsurg.142.5.467

74. Gruttadauria S, Marsh JW, Vizzini GB, et al. Analysis of surgical and perioperative complications in seventy-five right hepatectomies for living donor liver transplantation. World J Gastroenterol 2008;14:31593164. doi:10.3748/wjg.14.3159

75. Liu B, Yan LN, Li J, et al. Using the Clavien Grading System to Classify the Complications of Right Hepatectomy in Living Donors. Transplant Proc 2009;41:1703-1706. doi:10.1016/j.transproceed.2008.11.014 
76. Kim SJ, Na GH, Choi HJ, Yoo YK, Kim DG. Surgical Outcome of Right Liver Donors in Living Donor Liver Transplantation: Single-Center Experience with 500 Cases. J Gastrointest Surg 2012;16:1160-1170. doi:10.1007/s11605-012-1865-y

77. Li KW, Wen TF, Yan LN, et al. Donor right hepatectomy in living donor liver transplantation: report of 143 cases. Hepatogastroenterology 2010;57:1232-1236.

78. Taketomi A, Morita K, Toshima T, et al. Living donor hepatectomies with procedures to prevent biliary complications. J Am Coll Surg 2010;211:456-464. doi:10.1016/j.jamcollsurg.2010.04.018

79. Yuan D, Wei YG, Li B, et al. Evaluation outcomes of donors in living donor liver transplantation: A single-center analysis of 132 donors. Hepatobiliary Pancreat Dis Int 2011;10:480-488.

80. Yaprak O, Guler N, Altaca G, et al. Ratio of remnant to total liver volume or remnant to body weight: which one is more predictive on donor outcomes? HPB (Oxford) 2012;14:476-482. doi:10.1111/j.14772574.2012.00483.x

81. Shi ZR, Yan LN, Du CY. Donor safety and remnant liver volume in living donor liver transplantation. World J Gastroenterol 2012;18:7327-7332. doi:10.3748/wjg.v18.i48.7327

82. Yang YW, Lu JK, Qing EM, et al. Post-conditioning by xenon reduces ischaemia-reperfusion injury of the spinal cord in rats. Acta Anaesthesiol Scand 2012;56:1325-1331. doi:10.1111/j.1399. 6576.2012.02718.x

83. Shin M, Song S, Kim JM, et al. Donor morbidity including biliary complications in living-donor liver transplantation: single-center analysis of 827 cases. Transplantation 2012;93:942-948. doi:10.1097/ TP.0b013e31824ad5de

84. Salah T, Sultan AM, Fathy OM, et al. Outcome of right hepatectomy for living liver donors: a single Egyptian center experience. J Gastrointest Surg 2012;16:1181-1188. doi:10.1007/s11605-012-1851-4

85. Abecassis MM, Fisher RA, Olthoff KM, et al. Complications of Living Donor Hepatic Lobectomy. Am J Transplant 2013;12:1208-1217. doi:10.1111/j.1600-6143.2011.03972.x
86. Facciuto M, Contreras-Saldivar A, Singh MK, et al. Right hepatectomy for living donation: role of remnant liver volume in predicting hepatic dysfunction and complications. Surgery 2013;153:619-626. doi:10.1016/j.surg.2012.11.020

87. Wadhawan M, Kumar A, Gupta S, et al. Post-transplant biliary complications: an analysis from a predominantly living donor liver transplant center. J Gastroenterol Hepatol 2013;28:1056-1060. doi:10.1111/jgh.12169

88. Lei JY, Yan LN, Wang WT. Prediction factors of postoperative hyperbilirubinemia in living right lobe donor: a single-center analysis of 210 cases. Transplant Proc 2013;45:205-211. doi:10.1016/j. transproceed.2012.03.063

89. Usta S, Ates M, Dirican A, Isik B, Yilmaz S. Outcomes of left-lobe donor hepatectomy for living-donor liver transplantation: A singlecenter experience. Transplant Proc 2013;45:961-965. doi:10.1016/j. transproceed.2013.02.065

90. Ozgor D, Dirican A, Ates M, Gönültas F, Ara C, Yilmaz S. Donor complications among 500 living donor liver transplantations at a single center. Transplant Proc 2012;44:1604-1607. doi:10.1016/j. transproceed.2012.04.002

91. Lauterio A, Poli C, Cusumano C, et al. Living-donor liver transplantation: donor selection criteria and postoperative outcomes. A single-center experience with a 10-year follow-up. Transplant Proc 2013;45:2680-2683. doi:10.1016/j.transproceed.2013.07.037

92. Ozsoy M, Unalp O V., Sozbilen M, Alper M, Kilic M, Zeytunlu M. Results of surgery-related complications in donors of right lobe liver graft: analysis of 272 cases. Transplant Proc 2014;46:1377-1383. doi:10.1016/j.transproceed.2013.12.065

93. Dirican A, Ara C, Kutluturk K, et al. Donor Postoperative Biliary Complications After Living-Donor Liver Transplant. Exp Clin Transplant 2015;13:516-523. doi:10.6002/ect.2014.0117

94. Sun Z, Yu Z, Yu S, et al. Post-operative complications in living liver donors: A single-center experience in China. PLoS One 2015;10:e0135557. doi:10.1371/journal.pone.0135557 